\title{
A Question-Based Approach to the Design of a Successful "Finance for Non-Financial Managers" Executive Education Program
}

\author{
Mary Margaret Frank ${ }^{1}$, Mark E. Haskins ${ }^{1} \&$ Luann J. Lynch ${ }^{1}$ \\ ${ }^{1}$ The Darden Graduate School of Business, University of Virginia, Charlottesville, VA, USA \\ Correspondence: Luann J. Lynch, 100 Darden Blvd. Darden Graduate School of Business, University of Virginia, \\ Charlottesville, VA 22903, USA. E-mail: LynchL@darden.virginia.edu
}

Received: June 16, 2019

Accepted: July 12, 2019 Online Published: July 26, 2019

doi:10.5539/jel.v8n5p12

URL: https://doi.org/10.5539/jel.v8n5p12

\begin{abstract}
Many successful non-financial managers aspire to contribute at the larger table of management decision making. To do so necessitates broadening their skills to include financial acumen. For non-financial managers, learning new financial constructs can be daunting, and knowing when to use which tool is challenging. We describe a three-questions-based approach underlying the design and delivery of our successful one-week "Financial Management for Non-Financial Executives" program at the University of Virginia's Darden School of Business. We use a three-questions-based approach to facilitate the learning process in each of the following four financial arenas that comprise the overarching, larger financial acumen agenda.
\end{abstract}

- Modeling the financial effects associated with typical internal operating decision alternatives

- Assessing the impact of operating decisions on the financial statements produced for external constituents

- Assessing the impact of operating decisions on popular financial performance metrics used to compare and contrast companies

- Recognizing and incorporating the basic tax implications applicable to internal operating decision alternatives

For each of these four financial arenas, we outline three key questions tailored for each, using one comprehensive example to illustrate the application of our questions-based approach.

Keywords: executive education, program design, financial acumen, question-based learning

\section{Introduction}

Continued professional education is a key aspect of any organization's talent development agenda. Corporate initiatives to accomplish this objective for management-level personnel often entail a blend of on-the-job experiences, mentoring relationships, varied job assignments, professional conferences, online tutorials, and selected offsite topical educational programs. In this latter regard, and in response to a widespread demand for non-financial managers to acquire a basic financial acumen competency, many universities and business associations offer programs akin to "Financial Management for Non-Financial Executives". Specifically, this program title pertains to the one-week offering designed and delivered semi-annually by the University of Virginia's Darden School of Business. Typical of other such offerings elsewhere is the one-week residential version titled "Finance for Executives" at Northwestern University's Kellogg School of Management. Coursera offers a 17-hour, $100 \%$ online program titled "Finance for Non-Financial Managers", while the American Management Association provides non-financial managers a two-day residential program option called "Fundamentals of Finance and Accounting for Non-Financial Managers". No matter the title or the provider, such a topical program has been a longstanding, widely offered, well attended part of the executive education (EE) landscape (Note 1).

This article describes the strategy underlying the Darden School's successful "Financial Management for Non-Financial Executives" (FMNFE) program design and delivery. Specifically, it depicts the purposeful and effective use of questions "to facilitate [participant] learning and thinking" (Swart, 2010, p. 257; see also Petrini, 1994; Anonymous, 2005). Such depiction is intended to model for others the possibilities that they too might pursue in a similarly galvanized, questions-driven program design and delivery. Indeed, one of the challenges all 
EE program providers face is designing and delivering programs that provide "sticky" mechanisms, i.e., mechanisms that "facilitate the adhering of EE program learnings [so that they are] transferred back to work ... readily, easily, effectively, [and] substantively" (Haskins \& Clawson, 2006, p. 851). In this spirit, we believe that question-based learning is an effective, "sticky" mechanism and we want to encourage others to seek applicable means in their environments for the constructive and conscientious use of questions for guiding program architecture and facilitating program attendees' learning takeaways.

\section{The FMNFE Program Objectives}

Managers attending our FMNFE program have generally been successful in a variety of functionally-based roles in their organizations and are seeking to expand their capabilities to provide a more robust contribution at the table of management decision makers. Each one inevitably has risen to higher and higher levels in the organization, primarily based on their functional expertise. That is, the regional marketing manager may have risen through the ranks in either the sales side or brand management side. The general counsel executive may have moved up through the legal side of the organization, focusing on personnel, intellectual property rights, or environmental issues. The operations manager may have had years of experience in the production, purchasing, or quality control arena, or perhaps the construction side of the business. The human resource manager may have previously been focused on recruiting, benefits, or talent management. The engineering manager may have moved up over time by excelling not only as an engineer, but also as a project manager and then manager of engineers. What all such successful non-financial managers have in common, however, is an emergent realization that to continue on that upward path and to become a valued member of the management team, they must broaden their skill set to include financial acumen, a capability most have avoided, either intentionally or unintentionally. Each now wants to be and needs to be a full player.... each wants to contribute in a meaningful fashion to the financial topics under discussion...they want to be able to say to themselves, "I have expanded and constructively taken my PLACE at the enterprise-level discussion table."

Accordingly, the overall program objectives for our FMNFE program can be captured in the acronym PLACE, where the components collectively reflect the features of empowerment that non-financial attendees gain by learning financial acumen through the questions-based approach we use. We aim to help program attendees develop a broadened managerial mindset enhancing their financial:

\section{$\mathrm{P} \rightarrow$ PARTICIPATING}

\section{L $\rightarrow$ LISTENING}

A $\rightarrow$ ASKING

$\mathrm{C} \rightarrow$ CONTRIBUTING

\section{E $\rightarrow$ ETHICAL REASONING}

This acronym guides the instructors' thinking regarding both the overall program objectives to be accomplished and the planning for each individual class session. More specifically, through the week-long program, participants have the opportunity to develop an enhanced financial literacy (or acumen) that enables their PARTICIPATING in discussions in ways they have not been able to before; LISTENING with a different ear, one that recognizes

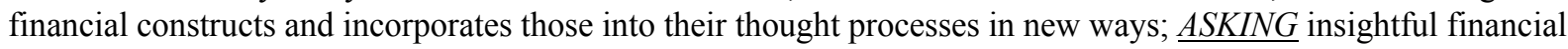
questions-knowing when to ask them and what questions to ask; confidently CONTRIBUTING to decision-making by taking a more holistic approach (one that considers not only their functional expertise but also financial implications); and bring to bear an ETHICAL REASONING regarding the managerial responses/actions galvanized by the financial measures they are subject to. At the program's opening and close, we alert attendees to these overarching, core objectives.

\section{The Program Content}

The content of our FMNFE program addresses four specific financial arenas. The first of these arenas pertains to the financial conventions used to internally evaluate operating and strategic decision alternatives. This arena is often referred to as "management accounting". Here, the focus is on understanding financial topics such as contribution analysis, cost behaviors, overhead cost allocations, budgeting and variance analysis, relevant cost analysis, discounted cash flows, multi-dimensional scorecards (e.g., balanced scorecards), and economic profit (e.g., economic value added). In the program, these measures and conventions are demonstrated, discussed, constructed, and interpreted at the business unit level, the product/service line level, department level, and the individual manager level.

The second arena, which is often referred to as "financial accounting", pertains to the financial conventions and 
content that companies use to communicate to external constituents-e.g., potential and current owners and lenders. Herein, the basic content of a company's annual report (or 10-K) is the focus. That content highlights the business segments' financial overview, the 5-year financial highlights, the business risks discussion often found in the Management Discussion \& Analysis section, the balance sheet, the income statement, the statement of cash flows, and the revenue recognition footnote. It is noteworthy that this latter focus provides a view into a company's business model, addressing the proverbial question of "how does this company make money?" The FMNFE program focus on this arena addresses the performance measurement issues at the enterprise level as conveyed to external constituents.

The third financial arena focusses on the popular, basic financial analysis protocols routinely performed by internal and external parties seeking to compare and contrast companies in regards to their financial health and performance. Here, issues related to indicators of financial strength/weakness, shareholder value creation, and enterprise performance beyond the absolute monetary amounts of the line items in the financial statements occupies some of the program's content. Key financial patterns, trends, and basic financial ratios are introduced, interpreted, and resultant implications for action are considered.

The fourth financial arena highlights the pervasive relevance of, and models the basic effects of, pertinent tax effects related to the operating decision alternatives a manager often faces. The purpose of this content is not to delve into a host of technical tax laws with the goal of learning to prepare a corporate income tax return. Rather, the purpose is to provide a framework for decision-making in a world with taxes - the real world. We build simple frameworks that outline the general ways tax law, no matter how technical, affect the cash flows from business decisions. The goal is to give non-financial managers an expanded lens with which to view operating decisions and recognize the related tax concerns in order to create better organizational financial awareness, so better decisions can then be made.

\section{The Fundamental Program Design Principle-Guiding Questions}

"The secret to getting the information you want and need is asking smart questions" (Leeds, 1993, p. 57). Indeed, learning of financial concepts by non-financial managers is facilitated by linking those important targeted concepts to the key questions that prompt their use. Gladis and Gladis $(2015$, p. 35) recently reiterated a common admonition that "an elegant solution to the wrong problem is simply a waste of time." Therefore, from an FMNFE program design perspective, helping participants to appropriately articulate and apply the key questions that their intuition, prior experience, and new insights lead them to ask is a core capability we seek to develop. Helping them to embrace and use a set of key questions has more staying power and more widespread applicability than simply filling their financial tool box without any linkages to what management decision contexts call for which tool. A tool box full of tools is not very useful without some guidance on how, when, and why each is to be used. "Learning leaders [e.g., EE program designers] must create an environment for thoughtful reflection and deep thinking so that people can begin to understand how they go about building and applying new knowledge. One way to accomplish this is to shift attention from outcome-oriented conversations to more process-driven conversations that focus more on asking questions" (Emelo, 2016, p. 42).

The use of questions to build the intellectual framework for an FMNFE program overall, and for that program's specific classes in particular, is helpful in sharpening focus, reducing ambiguity, and narrowing possibilities. Key questions ultimately assist in pointing to the most promising analytical path for a decision maker to take. Key questions engage learners to start with "what insights do I need to seek" as opposed to starting from a vantage point of "let me use this tool from my tool box to see what it might bring to light". In general, the use of guidance-providing questions is not new, as such efforts have been offered in other decision-oriented arenas. For example, Simons (2010) posits Seven Strategy Questions for improved strategy implementation; Dillavou (2002) provides "The Three Questions to Ask before Buying a Business"; Keller et al. (2002) present the "Three Questions You Need to Ask about Your Brand"; May (2012) writes about the "Three Questions Every CIO Must Answer"; Glassey (2008) argues for the use of three key questions in process modelling applications; and Ford et al. (2015, p. 377) offer six "key questions that every organization considering the use of crowdsourcing must address." We apply a similar approach in our FMNFE program design and class discussions. For each of the four financial arenas highlighted earlier, we rely on three tailored, galvanizing questions for each arena. Table 1 summarizes the discussion that follows pertaining to those questions and the financial arenas to which they pertain. 
Table 1. A three-question framework

\begin{tabular}{|c|c|c|c|c|}
\hline & $\begin{array}{l}\text { Management Accounting } \\
\text { Arena }\end{array}$ & $\begin{array}{l}\text { Financial Reporting } \\
\text { Arena }\end{array}$ & $\begin{array}{l}\text { Financial Analysis } \\
\text { Arena }\end{array}$ & Tax Arena \\
\hline & $\begin{array}{l}\text { Financial analysis of } \\
\text { internal operating decisions }\end{array}$ & $\begin{array}{l}\text { Assessing the impact of } \\
\text { decisions on financial } \\
\text { statements }\end{array}$ & $\begin{array}{l}\text { Assessing the impact of } \\
\text { decisions on key } \\
\text { performance metrics }\end{array}$ & $\begin{array}{l}\text { Incorporating tax } \\
\text { implications of decisions }\end{array}$ \\
\hline $\begin{array}{l}\text { Program content } \\
\text { implications } \\
\text { (Knowledge and } \\
\text { skills) }\end{array}$ & $\begin{array}{ll}\text { - } & \text { Cost behaviors } \\
\text { - } & \text { Contribution margin } \\
\text { - } & \text { Breakeven } \\
\text { - } & \text { Cost allocation } \\
\text { - } & \text { Activity based costing } \\
\text { - } & \text { Discounted cash flows } \\
\text { - } & \text { Net present value }\end{array}$ & $\begin{array}{ll}\text { - } & \text { Balance sheet } \\
\text { - } & \text { Income statement } \\
\text { - } & \text { Statement of cash } \\
\text { flow } & \\
\text { - } & \text { Financial } \\
\text { disclosiReasenue recognition }\end{array}$ & $\begin{array}{l}-\quad \text { Financial ratios } \\
\text { - } \quad \text { Performance } \\
\text { metrics }\end{array}$ & $\begin{array}{ll}\text { - } & \text { After-tax cash flows } \\
\text { - } & \text { Tax policy } \\
\text { - } & \text { Transfer pricing } \\
\text { - } & \text { After-tax return on } \\
\text { investments } \\
\text { - } & \text { Cost of debt }\end{array}$ \\
\hline $\begin{array}{l}\text { Guiding } \\
\text { questions }\end{array}$ & $\begin{array}{l}\text { 1) What is the operating } \\
\text { decision on our desk? } \\
\text { 2) What criterion should we } \\
\text { use to make that decision? } \\
\text { 3) What data do we need to } \\
\text { execute that criterion? }\end{array}$ & $\begin{array}{l}\text { 1) What part of this } \\
\text { financial picture changes? } \\
\text { 2) In what direction? } \\
\text { 3) By what amount? }\end{array}$ & $\begin{array}{l}\text { 1) What is the impact on } \\
\text { profitability? } \\
\text { 2) What is the impact on } \\
\text { productivity? } \\
\text { 3) What is the impact on } \\
\text { financial risk? }\end{array}$ & $\begin{array}{l}\text { 1) How does the decision } \\
\text { affect the tax base? } \\
\text { 2) How does the decision } \\
\text { affect the tax rate? } \\
\text { 3) How does the decision } \\
\text { affect the timing of the tax } \\
\text { consequences? }\end{array}$ \\
\hline
\end{tabular}

\subsection{Analyze the Financial Alternatives for the Internal Operating Decisions Arena}

As part of the decision-making process, managers must be able to analyze the financial outcomes of alternative operating decisions and strategies under consideration. The key questions we rely on for providing financial guidance to our program attendees for internal management decisions are, sequentially:

\section{1) What is the essence of the operating decision on his/her desk?}

2) What criterion should be used to make that decision?

\section{3) What data are needed to execute that criterion?}

Consider the following example. Suppose a manager is considering whether to raise or lower the price on a product in order to become more competitive and/or more profitable. The decision on the manager's desk may appear to be a pricing decision, and at one level it is. But, the decision to set a lower (higher) price inevitably results in a higher (lower) volume of product to be acquired and sold. So, the complete operating essence of the pricing decision involves ascertaining the volume/scale of product production, distribution, and service that she/he anticipates and wants to operate at. Why does that matter? Because, pricing decisions prompt volume changes, which prompt resource use changes, which prompt cost changes.

So, the most suitable, initial criterion to apply in this decision context is total profit at the various price and volume levels - all else equal, the manager would prefer the price/volume combination that generates the greatest total profit. But evaluating the impact of volume alternatives on profit may not be as easy as it initially seems. It may be that some of the costs the company incurs don't change between the volume levels under consideration. If so, then it becomes necessary to tease out which costs change with the amount of volume produced (variable costs), and which do not (fixed costs), so that the manager can accurately assess the true difference in profit between the two alternatives.

Thus, a more suitable criterion to apply in this decision context is total contribution (revenues minus variable costs) at the various price and volume levels - since some fixed costs will not differ between the alternatives, they do not impact the decision. As such, it becomes important for the decision maker to understand how their product or service costs behave when volumes change. However, since most companies present cost information to their managers according to the nature of the cost item (e.g., travel, supervision, insurance, payroll) and/or their point of origination (e.g., accounting, legal, manufacturing department \#27), and not by how they behave (e.g., variable versus fixed versus step function versus increasing at a decreasing rate), the burden is often on the decision maker to ascertain which costs will vary, and in what sort of pattern they will vary, as a result of the volume changes.

Let's push this a bit further. What if the option that generates a higher total contribution for the enterprise is the lower price/higher volume option, and to produce that higher volume, the manager must make an additional capital outlay to acquire more capacity? In that case, the criterion-to-use key question generates an answer of 
return on investment. The additional-data-needed key question points to the necessity of measuring the additional investment required to produce at that increased volume level. That realization then requires acknowledging that the investment occurs upfront, with the benefits derived over subsequent periods of time; in this case, the manager must take into account that a dollar today is worth more than a dollar in the future. So, it is important to then take into account the time value of money and a discounted cash flow analysis emerges as important to do. And, the appropriate criterion is net present value (NPV), and the manager would prefer the alternative that generates the highest NPV. Such an analysis would compare the NPV of future yearly cash flow contributions from the higher price/lower volume alternative (which requires no initial investment) to the NPV of the lower price/higher volume alternative.

Applying our three-question-based approach to considering financial factors in operating decision-making requires knowledge and skills that the non-financial manager either may not have in his/her toolbox, or that need sharpening if they have been placed in that toolbox at some point in the past but have become rusty from lack of use. The first column in Table 1 presents examples (not all-inclusive) of some of the knowledge and skills that may be relevant to managers as they seek to assess the internal financial assessment of various alternatives when making significant operating decisions. Which skill should be applied in what decision context? The three questions posed facilitates non-financial managers knowing how to best proceed. Those knowledge and skills become part of the manager's repertoire, and the manager learns to use a three-question approach to guide his/her selection of the most appropriate tool when assessing operating decision alternatives.

\subsection{Assessing the Impact of Operating Decisions on the Arena of the External Financial Statements}

Non-financial managers make many decisions that have a financial impact on the organization as reflected in the organization's financial statements produced for external constituents. And certainly, readers and users of those publicly available financial statements, such as analysts, investors, and creditors, use company financial statements to glean important insights into the merits of the decisions that those managers providing the financial statements have made. Accordingly, it is important for managers to proactively anticipate and assess the impact of their business decisions on those external financial statements.

The external financial statements of an entity can, at its most basic level, be robustly depicted as in Figure 1.

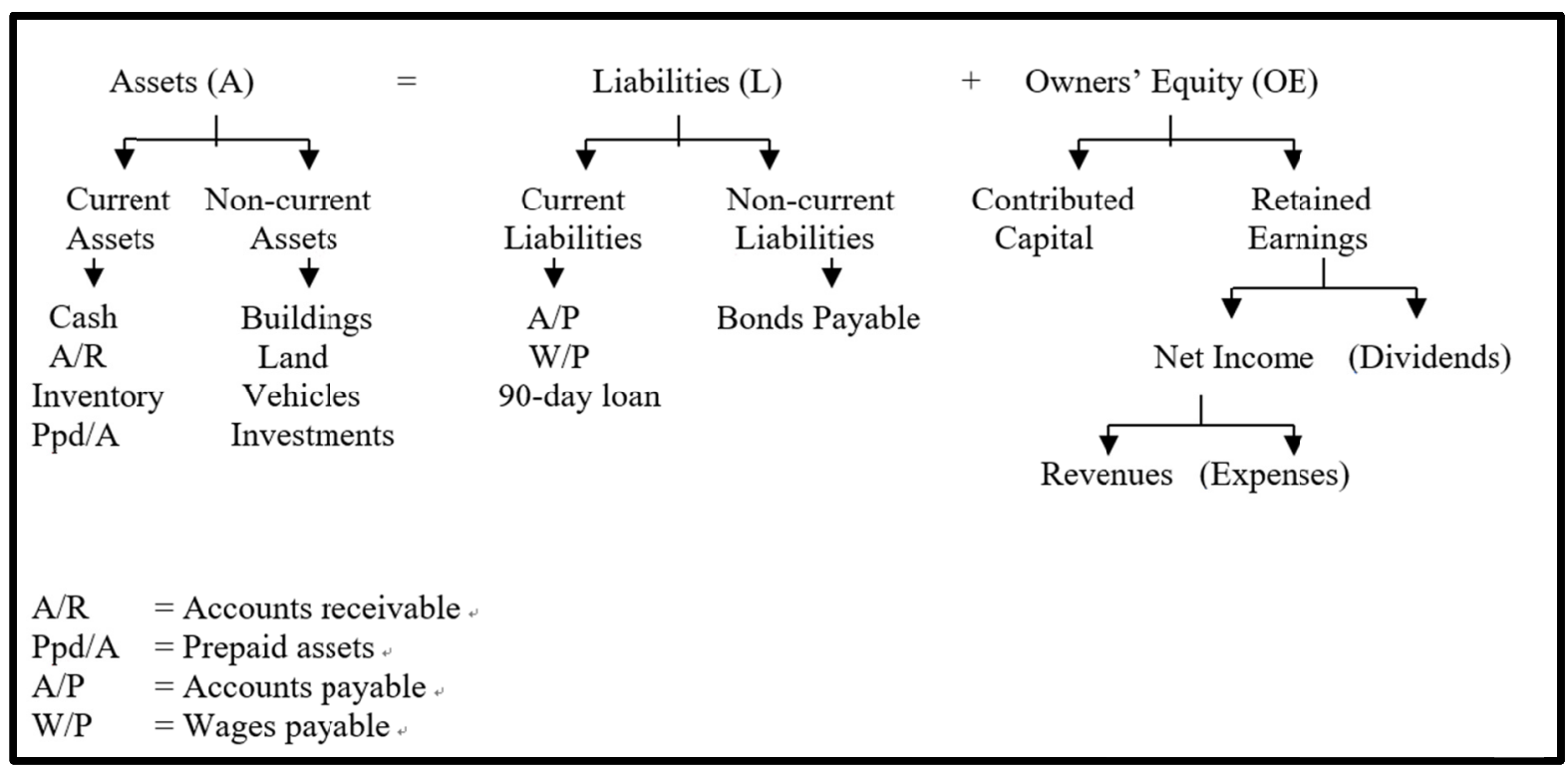

Figure 1. External financial statement elements and connections (the balance sheet and income statement)

Source: Adapted from a similar exhibit in M. Haskins, The Secret Language of Financial Reports. (New York: McGraw-Hill, 2008).

Three fundamental questions can be used to guide managers in proactively assessing the potential impact of their decisions on that financial picture:

1) What part of this financial picture (Figure 1) changes as a result of the decision?

2) In what direction? 


\section{3) By what amount?}

Let's consider again the case of the prior example of a price/volume decision. The manager must be able to envision the impact of his/her decision on the external financial statements. Consider the part of the financial picture known as the income statement, which contains revenues and expenses. Managers must be able to envision how each price/volume alternative will affect profit, either by increasing revenues due to different prices and volume levels, and/or by changing the costs.

Now consider that the lower price/higher volume alternative may require the investment in additional capacity to handle the increased volume. Then, the manager must consider, for example, the part of the financial picture known as the balance sheet, which contains assets (those things the organization has invested in and owns or controls), as well as liabilities and owners' equity (the two general sources from which the organization has obtained the funds to invest in those assets). The manager must be able to envision how those parts of the external financial statements' picture changes when he/she evaluates the decision of whether to invest in that additional capacity — assets will increase and cash will decrease (or liabilities will increase) by the amount of the purchase.

The impact on the financial statements, collectively called here the "financial picture", is an important consideration, as that impact will affect the perception of external readers/users of those financial statements about the company's financial health and performance. Indeed, C-suite executives are not ambivalent about the financial picture conveyed to outside parties so all key operating decisions, with a potentially significant impact on those external financial statements, should be filtered through these three key questions before a final decision is made.

The second column in Table 1 presents examples (not all-inclusive) of some of the financial tools most applicable to the external financial statements arena. These include an understanding of the basic published financial statements and their components (alluded to in the above example) and a basic understanding of the company's financial disclosures to external audiences. In our FMFNE program, those knowledge and skills become part of the manager's toolbox, and managers learn to use the three-questions pertinent to this arena to guide him/her in using them when assessing the impact of their decisions on the external financial statements.

\subsection{Assessing the Impact of Operating Decisions for the Key Performance Metrics Arena}

All managers, including non-financial managers, are well-served to anticipate how their decisions will affect the performance metrics used internally, as well as those applied externally, when companies are compared and contrasted. Three fundamental questions can guide managers in assessing the impact of decisions on key performance metrics of concern:

\section{1) What is the impact of a decision on profitability?}

2) What is the impact of a decision on productivity?

\section{3) What is the impact of a decision on financial risk?}

As a starting point, these three questions prompt a classic DuPont analysis - an analysis through which return on equity (ROE), a fundamental metric used in assessing a company's performance, is deconstructed into ratios capturing profitability (return on sales, or ROS), productivity (asset turnover, or AT), and financial risk (financial leverage, or FL).

$$
\text { ROE } \quad \text { ROS } \quad \mathrm{x} \quad \mathrm{AT} \quad \mathrm{x} \quad \mathrm{FL}
$$

Or:

$$
\text { Net Income/Equity }=\text { Net Income/Sales } \times \text { Sales/Assets } \times \text { Assets/Equity }
$$

Each of these three ratios then has drill-down possibilities for additional granularity and insight; they can be further deconstructed to highlight for managers where the underlying root cause of the increase/decrease to a particular ratio lies (Figure 2). For example, asset turnover can be more specifically scrutinized via an inventory turnover metric and/or a days' sales outstanding measure. Likewise, return on sales can be more specifically scrutinized via a gross margin metric or an operating-profit-as-a-percent-of-sales measure. 


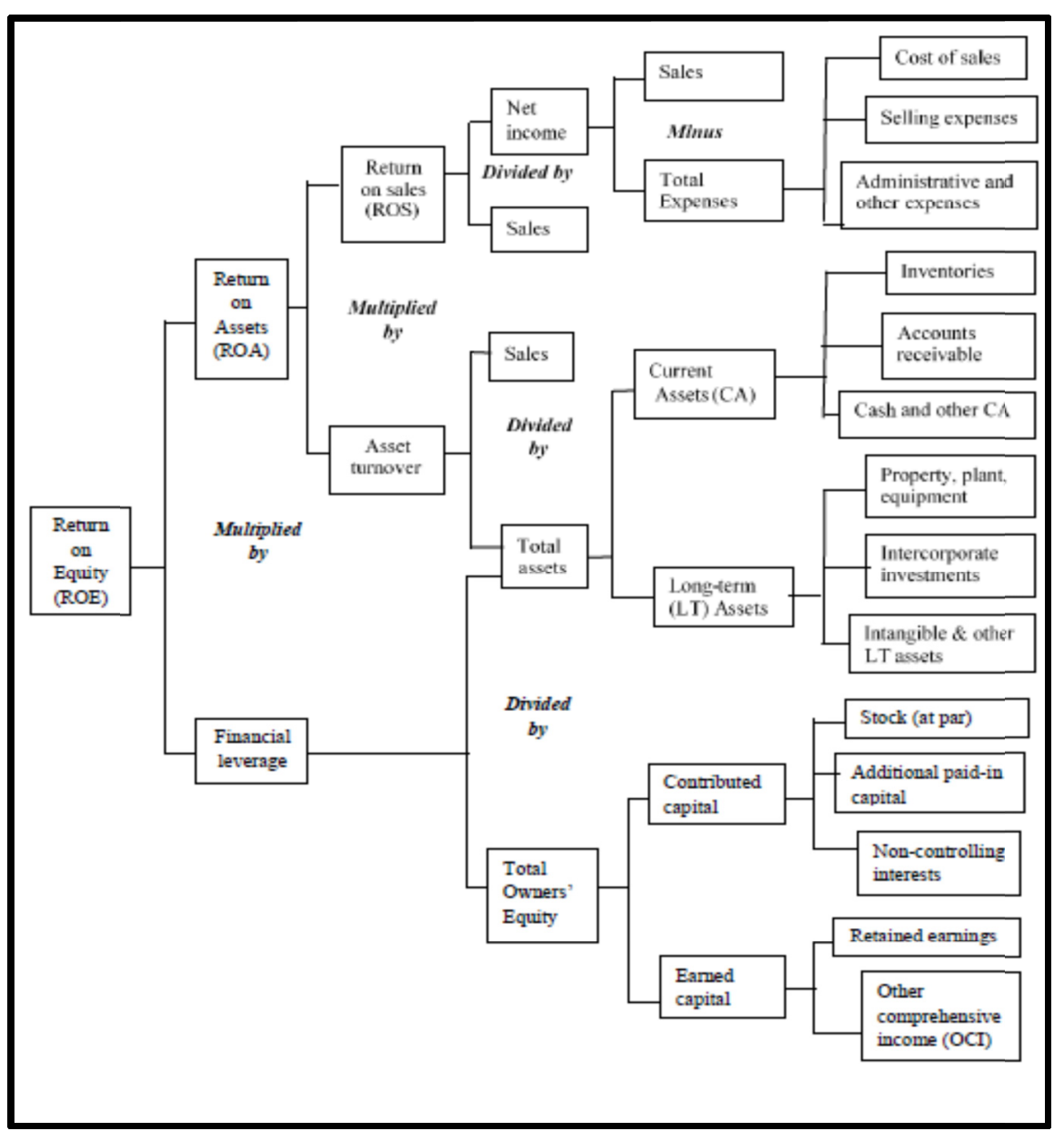

Figure 2. Factors affecting return on sale, return on assets, and return on equity

Source: Mark E. Haskins, "Ratios Tell a Story—2017 (Teaching Note)," UVA-C-2410TN (Charlottesville, VA: Darden Business Publishing, 2018).

Again, consider the example we have been using regarding the price/volume decision. Managers should be able to envision how each price/volume alterative will affect profit, revenues, and thus ROS, which is a key profitability indicator.

Now consider, as was teed up earlier, that the lower price/higher volume alternative may require the investment in additional capacity to handle the increased volume. The manager should note that this option will impact productivity (i.e., asset turnover) as both sales and assets increase through the investment in capacity. Then, the manager can note the impact on financial risk, depending on the method chosen to finance that investment. Ultimately, each of these financial performance effects results in an impact on the organization's return on equity measure. As with the external financial statements, C-suite executives are concerned about certain financial ratios and what they communicate about the organization's performance and financial health, particularly when debt covenants require certain ratios be maintained, or equity analysts use the metrics to compare the company to its peers and competitors.

Applying this three-question-based approach to the arena of financial performance measures used by an array of constituents requires knowledge and skills that non-financial managers either may not have in their toolbox, or that need sharpening if they have been placed in that toolbox at some point in the past but have become rusty from lack of use. Table 1, third column, presents examples (not all-inclusive) of some of those financial analysis tools that may be relevant to managers as they seek to assess the impact of their decisions on key organization-level performance metrics frequently used to compare and contrast their company with others. In our FMFNE program, those knowledge and skills become part of the manager's toolbox, and the manager again learns to use a tailored three-question approach to guide him/her in using them when assessing the impact of their decisions on the key organizational metrics. 


\subsection{Incorporating the Tax Implications Arena into Management Decision-Making}

Even managers with backgrounds in accounting and finance shy away from embracing the implications of taxes in operating decisions because of the common anxiety generated in filing their own personal tax return based on ever-changing, and often incomprehensible, tax laws. While the tax laws never stay the same for very long and are potentially quite complex, the basic implications of any tax law on business decisions can be boiled down to three key questions:

\section{1) How does the decision affect the tax base? \\ 2) How does the decision affect the tax rate? \\ 3) How does the decision affect the timing of the tax consequences?}

The first and second questions assess the size of the tax consequences, whether it is a liability owed or a benefit received. "Tax base" is simply a term that generalizes the first question to consider more than income as the "what" that is being taxed. While income is the tax base familiar to most, businesses face many systems with different tax bases - sales, value-added, wages, and property are a few examples in that regard. The third question points to the need to possibly consider the present value of the cash flows stemming from the anticipated tax consequences. Combined, these three questions emphasize that when making decisions, after-tax monetary amounts need to be considered.

A manager is well served to be able to quickly assess the possible tax implications of a decision and estimate their financial materiality before turning to an expert. Consider our earlier price/volume example. The decision to change the price, combined with the resulting change in volume, will affect the tax base (i.e., income) through changes in revenue. The changes in volume will also decrease the tax base by increasing the cost of goods sold expense deduction. Further, if sales and production occur in different countries, and those countries have different tax rates, the tax consequences for the company will be affected by the transfer prices it establishes.

Introducing the need for an upfront investment in the price/volume decision adds the important additional consideration of the timing of the tax consequences. As posed above, the cash outlay for the investment increases the assets on the balance sheet. It does not reduce income immediately. Instead, the company reduces income over time through the annual depreciation of the asset. The annual depreciation is deductible for tax purposes, so it reduces that tax base. While the annual depreciation is not itself a cash outflow, the tax savings (depreciation deduction $\mathrm{x}$ tax rate) generated from it is. Therefore, the NPV analysis discussed in Section 4.1 must consider the cash inflow from the tax savings over the life of the asset, which is a function of the size of the annual depreciation deduction and the company tax rate. If the government allows the investment to be fully deductible for tax purposes at the end of the first year (i.e., bonus depreciation), which it often does, the NPV will increase because the tax savings will provide the company the cash tax savings sooner (year 1) rather than later (spread over several years). If the company borrows funds to make the investment, the organization pays interest on the use of funds. If the interest is deductible, the deduction generates tax savings, reducing the cost of debt. Again, the tax savings is the deduction (interest) $\mathrm{x}$ tax rate, and the timing of the deduction will affect the present value of the cost of debt.

Applying our tailored three-questions-based approach to address the tax implications of decision-making requires prompts the recollection of and the appropriate selection of just the right financial tool for assessing the tax implications. The fourth column in Table 1 presents examples (not all-inclusive) of the knowledge and skills that may be relevant to managers as they seek to assess the tax implications of their decisions. These include an understanding of the effect of tax bases, tax rates and timing on production, location, investment and financing decisions (all alluded to in the above example), among many others. In our FMFNE program, those knowledge and skills become part of the manager's toolbox, and the manager learns to use a three-question approach to guide him/her in using them when assessing the materiality of tax implications on their decisions.

\section{Conclusion}

It is worth repeating that, "The secret to getting the information you want and need is asking smart questions" (Leeds, 1993, p. 57). That belief informs our FMNFE program design and our in-class assignments and discussions with program participants. For non-financial managers, learning a new array of financial terms, techniques, concepts, and principles can be an overwhelming experience. Even after filling one's toolbox with a broad array of financial knowledge and skills, deciding when to use which tool is a challenge in itself. Key questions, tailored to each of four fundamental financial arenas are helpful in sorting the relevant data from the irrelevant and selecting the appropriate tool(s).

Over the years, we have found the guiding questions framework helpful in refining the program design, orienting 
new faculty to the program team, and helping to make program learning "sticky" (i.e., memorable and recallable) for the program attendees. As long as those who have completed our FMNFE program continue to provide feedback such as ...

"This program addressed a significant blind spot in my work skillset and has given me a shot of epinephrine so that I can now engage the heavier and meatier financial aspects of my business with more accuracy, relevant theory, and natural thought process."

"The faculty of Darden do a terrific job explaining a quick overview of financial management so you can ask the right questions and be a more informed manager.... I was able to apply the concepts and topics taught throughout the course to real life situations that I will take home with me and be able to use on a daily basis within my industry."

... we will continue to be guided by and reliant on the questions that have helped empower those program attendees to be able to say, "I have found my PLACE at the management discussion table in the enterprise."

\section{Acknowledgements}

The authors gratefully acknowledge the financial support of the University of Virginia Darden School Foundation.

\section{References}

Anonymous. (2005). The power of questions. Leader to Leader, 36, 59-60. https://doi.org/10.1002/lt1.129

Dillavou, J. (2002). The three questions to ask before buying a business. International Tax Review, 13(10), 1618.

Emelo, R. (2016). Ask Me Anything: The power of questions in learning. Chief Learning Officer, 15(8), 40-53.

Ford, R., Richard, B., \& Ciuchta, M. (2015). Crowdsourcing: A new way to employing non-employees? Business Horizons, 58(4), 377-388. https://doi.org/10.1016/j.bushor.2015.03.003

Gladis, S., \& Gladis, K. (2015). Coaching through questions. Talent Development, 69(3), 32-36.

Glassey, O. (2008). A case study on process modelling - Three questions and three techniques. Decision Support Systems, 44(4), 842-853. https://doi.org/10.1016/j.dss.2007.10.004

Haskins, M., \& Clawson, J. (2006). Making it sticky: How to facilitate the transfer of executive education experiences back to the workplace. Journal of Management Development, 25(9), 850-869. https://doi.org/10.1108/02621710610692052

Keller, K., Sternthal, B., \& Tybout, A. (2002). Three questions you need to ask about your brand. Harvard Business Review, 80(9), 81-86.

Leeds, D. (1993). The art of asking questions. Training \& Development, 47(1), 57-62.

May, T. (2012). Three questions every CIO must answer. Computerworld, 46(19), 14.

Petrini, C. (1994). Strategies for learning. Training \& Development, 48(3), 19.

Simons, R. (2010). Seven Strategy Questions: A Simple Approach for Better Execution. Boston: Harvard Business Review Press.

Swart, A. (2010). Evaluation of final examination papers in engineering: A Case Study Using Bloom's Taxonomy. IEEE Transactions on Education, 53(2), 257-264. https://doi.org/10.1109/TE.2009.2014221

\section{Note}

Note 1. The Darden School's "Financial Management for Non-Financial Executives" program was first offered in 1978 and has been offered at least twice a year ever since, with over 370 attendees in the past 10 years.

\section{Copyrights}

Copyright for this article is retained by the author, with first publication rights granted to the journal.

This is an open-access article distributed under the terms and conditions of the Creative Commons Attribution license (http://creativecommons.org/licenses/by/4.0/). 